\title{
Telomerase is strongly activated in hepatocellular carcinoma but not in chronic hepatitis and cirrhosis
}

\author{
Young Min Park, ${ }^{1,2,3}$ Jong Young Choi, ${ }^{1,2,3}$ \\ Byung Hun Byun, ${ }^{1,2,3}$ Chang Hoon Cho, ${ }^{2,3}$ \\ Hee Sun Kim ${ }^{2,3}$ and Boo Sung Kim ${ }^{1,2}$ \\ 1 Department of Internal Medicine, Kangnam St. Mary's Hospital, \\ College of Medicine The Catholic University, Seoul 137-040, Korea \\ 2 WHO Collaborating Centre for Reference and Research on Viral \\ Hepatitis in Korea \\ 3 Molecular Hepatology Laboratory, Institute of Human Molecular \\ Genetics, Catholic Research Institutes of Medical Science, \\ The Catholic University of Korea, Seoul 137-040, Korea \\ 3 Corresponding author \\ Accepted 7 March 1998
}

Abbreviations: TRAP, telomeric repeat amplification protocol; HCC, hepatocellular carcinoma

\begin{abstract}
Telomerase is highly activated in human immortal cell lines and tumor tissues, whereas it is not activated in primary cell strains and many tumor-adjacent tissues. It is suggested that telomerase activation is one of the critical steps in malignant transformation. In the present study, the telomerase activity was investigated in hepatocellular carcinoma tissues and non-tumor liver tissues from Korean patients with chronic hepatitis and cirrhosis. Eighty two liver tissues (24 chronic hepatitis specimens, 34 cirrhosis specimens, and 24 hepatocellular carcinomas) were obtained from 23 chronic viral hepatitis patients, 19 cirrhosis patients (including 7 liver transplants), and 24 patients with hepatocellular carcinoma, of which the surrounding non-tumor liver tissues were available in 16 patients (1 chronic hepatitis and 15 cirrhosis). As negative controls, 3 normal liver tissues were included. Protein from liver specimens was purified by a detergent lysis method as described elsewhere, and telomerase activity was measured in 2 diluents of each sample (1:1 and $1: 100)$ by a telomeric repeat amplification protocol (TRAP). Telomerase was strongly activated in $79 \%$ $(19 / 24)$ of the hepatocellular carcinomas, while weakly in $8 \%(2 / 24)$ of the chronic hepatitis tissues and in $24 \%(8 / 34)$ of the cirrhosis tissues. All of 3 normal control livers showed no telomerase activation. No relationship could be observed between the enhancement of telomerase activity and
\end{abstract}

tumor nature. None of the chronic hepatitis or cirrhosis patients with mild telomerase activation in the liver have developed hepatocellular carcinoma for at least 2 years of follow-up period. These results suggest that the strong enhancement of telomerase activity may be a critical part of hepatocarcinogenesis, although the exact mechanism of such high activation in hepatocellular carcinoma is not clear. In addition, further study will be necessary to clarify the reason why no telomerase activity detectable by a conventional TRAP can be seen in some hepatocellular carcinoma.

Keywords: telomerase activity, TRAP, hepatocellular carcinoma, HCC, chronic hepatitis, cirrhosis

\section{Introduction}

Telomeres, specialized structures at the ends of all eukaryotic chromosomes, which are composed of 10-15 kilobases of TTAGGG repeats, play a critical role for protecting termini of the chromosomes from the devastating attack of exonuclease and ligase (Blackburn and Gall, 1978; Moyzis et al., 1988; Blackburn, 1991). In addition, it has been considered that these telomeres are the mitotic clock of normal human somatic cells, because the shortening in length of these telomeric DNAs is associated with the decrease of in vivo division of the cells (Harley et al., 1990; Lindsey et al., 1991; Allsopp et al., 1992), and, by such a mechanism, cells count their division cycles. All immortal cells have no net loss of telomeric length with cell division, suggesting that the maintenance of telomeres is required for the cells to escape from replicative senescence and to proliferate indefinitely (Counter, 1992; Counter et al., 1994; Counter et al., 1994).

It has been found that the preservation of the telomeric length is associated with the activation of telomerase, a ribonucleoprotein, which synthesizes the telomeric DNA onto chromosomal ends using a segment of its RNA component as a template (Greider and Blackburn, 1985). Reportedly, the telomerase is activated in many human tumor tissues and immortal cell lines (Greider and Blackburn, 1985; Counter et al., 1994; Kim et al., 1994). Like other malignant cells, most hepatocellular carcinomas also had the enhancement of the telomerase activity (Tahara et al., 1995; Nouso et al., 1996; Kojima et al., 1997). In addition, it was suggested that telomere shortening might play an important role in the associated generation of hepatocellular carcinoma (Ohashi et al., 1996), although there was a controversial result (Kojima et al., 1997). In the present study, telomerase activity of 
hepatocellular carcinoma was analyzed and compared to that of non-tumor liver tissues from Korean patients with chronic hepatitis or cirrhosis which was the precancerous diseases of hepatocellular carcinoma to investigate the role of telomerase in hepatocarcinogenesis.

\section{Materials and Methods}

\section{Liver tissues}

Liver tissue specimens were collected from 66 patients with chronic liver diseases, consisting of 23 chronic hepatitis, 19 cirrhosis (including 7 liver transplants), and 24 hepatocellular carcinoma, while 3 controls without any evidences of liver diseases, on whom operation was performed for the treatment of early gastric cancer. They were from the Department of Internal Medicine, Kangnam St. Mary's Hospital, The Catholic University, Seoul, Korea, from 1991 to 1995. Out of these patients, 85 liver tissues were obtained by blind liver biopsy, laparoscopic biopsy, ultrasono-guided biopsy, or operative biopsy. In 16 of the 24 patients with hepatocellular carcinoma, a pair of both tumor and surrounding non-tumor tissues were available, so that the liver tissues consisted of 24 chronic hepatitis specimens ( 1 from a patient with hepatocellular carcinoma), 34 cirrhosis specimens ( 15 from patients with hepatocellular carcinoma), 24 hepatocellular carcinomas. And six hepatoma cell lines originating from liver cancers, HuH7, Hep G2, 2.2.15., Hep3B, HLE and HLF, were also examined.

The 66 patients consist of 14 females and 52 males and ranged from 19 to 65 years (mean 40 years). Hepatitis B surface antigen (HBs $\mathrm{Ag}$ ) was positive in 55 patients (83\%), antibody to hepatitis $\mathrm{C}$ virus (anti-HCV) was positive in 3 patients (4.5\%), and both $\mathrm{HBs} \mathrm{Ag}$ and anti$\mathrm{HCV}$ tests were negative in 8 patients $(12 \%)$. In accordance with the WHO classification for chronic hepatitis and the Edmondson-Steiner criteria for hepatocellular carcinoma (Edmondson and Steiner, 1954), liver tissues were histologically interpreted.

\section{Serological markers}

HBsAg, antibody to HBsAg (anti-HBs), Hepatitis B e antigen (HBe $\mathrm{Ag}$ ), antibody to $\mathrm{HBeAg}$ (anti-HBe), and total antibody to hepatitis $B$ core antigen (anti-HBc) were assayed using commercially available radioimmunoassay kits (Abbott Laboratories, Chicago, IL, USA). Anti-HCV was assayed with a second generation enzyme immunoassay kit (Abbott Laboratories).

\section{Extraction of protein}

By a detergent lysis method (Counter et al., 1994; Kim et al., 1994), both protein and nucleic acids from tissue specimens were obtained simultaneously. Briefly, liver tissues were homogenized with $50 \mu \mathrm{l}$ of cold lysis buffer (10 mM Tris $\mathrm{HCl}, \mathrm{pH} 7.5,1 \mathrm{mM} \mathrm{MgCl} 2,1 \mathrm{mM}$ ethylene glycol-bis ( $\beta$-aminoethyl ether) N,N,N,N-tetraacetic acid, $0.1 \mathrm{M}$ phenylmethylsulfonyl fluoride, $5 \mathrm{mM} \beta$-mercaptoethanol, 0.5\% 3-[(3-cholamidopropyl)-dimethyammonio]1 -propanesulfate, and $10 \%$ glycerol. After incubation for $25 \mathrm{~min}$ on ice, the lysate was centrifuged at $10,000 \mathrm{~g}$ for $30 \mathrm{~min}$. The supernatant was quickly frozen and stored at $-80^{\circ} \mathrm{C}$. And protein concentration was measured by a Bradford method (Sharma et al., 1980).

\section{Measurement of telomerase activity}

Telomerase activity in an aliquot (6 $\mu \mathrm{g}$ of protein) of the extracts isolated from each tissue sample was measured by the telomeric repeat amplification protocol (TRAP) (Kim et al., 1994). Briefly, assay tubes were prepared by lyophilizing $0.1 \mu \mathrm{g}$ of $\mathrm{CX}$ primer sequence [5'-(CCCTTA $)_{3}$ CCCTAA-3'] onto the bottom of the tube and sealing it with $10 \mu \mathrm{l}$ of molton wax (Ampliwax, Perkin Elmer, Norwalk, $\mathrm{CT}$, USA). The assay mixture (50 $\mu \mathrm{l})$ containing $20 \mathrm{mM}$ Tris- $\mathrm{HCl}\left(\mathrm{pH}\right.$ 8.3), $1.5 \mathrm{mM} \mathrm{MgCl}_{2}, 63 \mathrm{mM} \mathrm{KCl}, 0.005 \%$ Tween-20, $1 \mathrm{mM}$ ethyleneglycoltetraacetic acid, $50 \mu \mathrm{M}$ deoxynucleoside triphosphate, $0.1 \mu \mathrm{g}$ of TS primer (5'AATCCGTCGAGCAGAGTT-3'), $1 \mu \mathrm{g}$ of T4g32 protein (Boehringer Mannheim, Mannheim, Germany), bovine serum albumin (BSA; $0.1 \mathrm{mg} / \mathrm{ml}), 2 \mathrm{U}$ of Taq DNA polymerase (Boehringer Mannheim), $0.3 \mu$ of $\left[\alpha^{32} P\right]-$ deoxycytidine triphosphate $(3000 \mathrm{Ci} / \mathrm{mmol}$; Amersham, UK) and $2 \mu \mathrm{l}$ of extracted samples were placed in the prepared tube. After incubation at $23^{\circ} \mathrm{C}$ for $30 \mathrm{~min}$, the tubes subjected to 31 polymerase chain reaction (PCR) cycles at $94^{\circ} \mathrm{C}$ for $30 \mathrm{sec}, 52^{\circ} \mathrm{C}$ for $30 \mathrm{sec}, 72^{\circ} \mathrm{C}$ for 45 sec. The final extension reaction was performed at $72^{\circ} \mathrm{C}$ for $2 \mathrm{~min}$. PCR products were analyzed by electrophoresis on $10 \%(19: 1)$ polyacrylamide nondenaturating gels in $0.5 X$ Tris-borate EDTA buffer ( $\mathrm{pH} 8.0$ ). After the gel was dried, autoradiogram (Hyperfilm ${ }^{\mathrm{TM}}-\mathrm{MP}$, Amersham) was processed with an exposure at $-80^{\circ} \mathrm{C}$ for $24 \mathrm{~h}$. The data were collected in a blind fashion and decoded later.

For the quantitative measurement of telomerase activity, each aliquot ( $6 \mu \mathrm{g}$ of protein) from individual extracts were diluted to and 1:100 (0.06 $\mu \mathrm{g}$ of protein) by the published method (Tahara et al., 1995; Kojima et al., 1997; Yashima et al., 1997) and the telomerase activity was examined. Final results obtained from individual samples were compared to those from a positive control by visual observation and a densitography (ImageMaster VDS and image master software, Pharmacia Biotech Asia Pacific Ltd., Hong Kong, China), and the telomerase activity was arbitrarily defined into 3 groups; 'strong' if the multiple ladder-like amplification bands of individual sample were similar to those of positive control in densities of the sixth to seventh bands from the first band at the base line, 'weak' if they were seen only in an undiluted sample, and 'moderate' if they were between strong and 
weak results. Samples which showed no bands or only one or two faint bands in the undiluted sample were defined as negative results. In all experiment, at least 3 controls were included; Huh7 cell line as a positive control, a piece of normal liver as a negative tissue control, and distilled water as a negative control to differentiate the carryover contamination during the experiments.

\section{Statistical Analysis}

Statistical analyses were performed with Student's $t$ test and $\chi^{2}$ test.

\section{Results}

Telomerase was strongly activated in 19 of 24 hepatocellular carcinomas $(79 \%)$ and in all of 6 hepatoma cell lines. Intensities of the telomerase activity from these 19 positive samples could not be differentiated from those of hepatoma cell lines and each other. On the contrary, telomerase activity was weakly detected in 10 of 59 nontumorous liver tissues (16.9\%); 2 of 24 chronic hepatitis specimens ( $8 \%)$ and 8 of 35 cirrhosis specimens (24\%). All of 3 negative control liver tissues had no telomerase activity. (Figure 1 and Table 1)

Regarding 5 hepatocellular carcinomas negative for TRAP, no cases had a paradoxical phenomenon which shows higher enhancement level of the telomerase activity in serially diluted sample than in undiluted sample. So, a serial dilution method was not beneficial to identify further cases with telomerase activation.

Comparing with that in chronic hepatitis without hepatocellular carcinoma $(1 / 23,4 \%)$, the frequency of telomerase activity in cirrhosis without hepatocellular carcinoma was significantly high $(5 / 19,26 \%)(p=0.049)$. However, no patients with telomerase activation have

Table 1. Results of telomerase activity measurement in liver specimens from chronic hepatitis, cirrhosis, and hepatocellular carcinomas.

\begin{tabular}{lrrrr}
\hline & $\begin{array}{c}\text { No. of cases } \\
\text { tested }\end{array}$ & \multicolumn{3}{c}{ Telomerase activation } \\
& No. of cases & $(\%)$ & (Weak/Strong) $^{\mathrm{b}}$ \\
\hline Chronic hepatitis & 24 & 2 & $(8 \%)$ & $(1 / 1)$ \\
$\quad$ without HCC & 23 & 1 & $(4 \%)$ & $(1 /-)$ \\
$\quad$ with HCC & 1 & 1 & $(100 \%)$ & $(-/ 1)$ \\
Liver cirrhosis & 34 & 8 & $(24 \%)$ & $(8 / 0)$ \\
$\quad$ without HCC & 19 & 5 & $(26 \%)$ & $(5 /-)$ \\
$\quad$ with HCC & 15 & 3 & $(20 \%)$ & $(3 /-)$ \\
Hepatocellular carcinoma & 24 & 19 & $(79 \%)$ & $(0 / 19)$ \\
Normal Liver & 3 & 0 & - & $(-/-)$ \\
\hline
\end{tabular}

HCC: Hepatocellular carcinoma.

${ }^{\text {a }}$ Liver tissues from 7 transplantation recipients were included; 2 of them were weak positive in TRAP assay.

' It was arbitrarily considered for the telomerase activity to be 'strong' if the multiple ladder-like amplification bands of individual sample are similar to those of positive control in densities of the sixth to seventh bands from the first band at the base line, 'weak' if they are seen only in an undiluted sample, and 'moderate' if they were between strong and weak results. Samples which showed no bands or only one or two faint bands in the undiluted sample were defined as negative results.

Figure 1. Representative figures of telomerase activity in 17 chronic liver disease, 4 hepatocellular carcinoma, and 2 normal liver tissues. Tumor tissues (T71-T74), which showed detectable telomerase activity by TRAP, had the multiple amplification bands as strong as those of a positive control (PC; Huh7 cell line), so that high telomerase activity could be seen in 1:100 dilution of sample. However, in non-tumor liver tissues like chronic hepatitis $(\mathrm{CH})$ or cirrhosis $(\mathrm{LC})$, telomerase activity was usually negative, although few cases (LC65, LC67, CH51, $\mathrm{CH} 53$ ) showed weak amplification bands. NL, normal liver (negative tissue control); NC, negative control (distilled water).
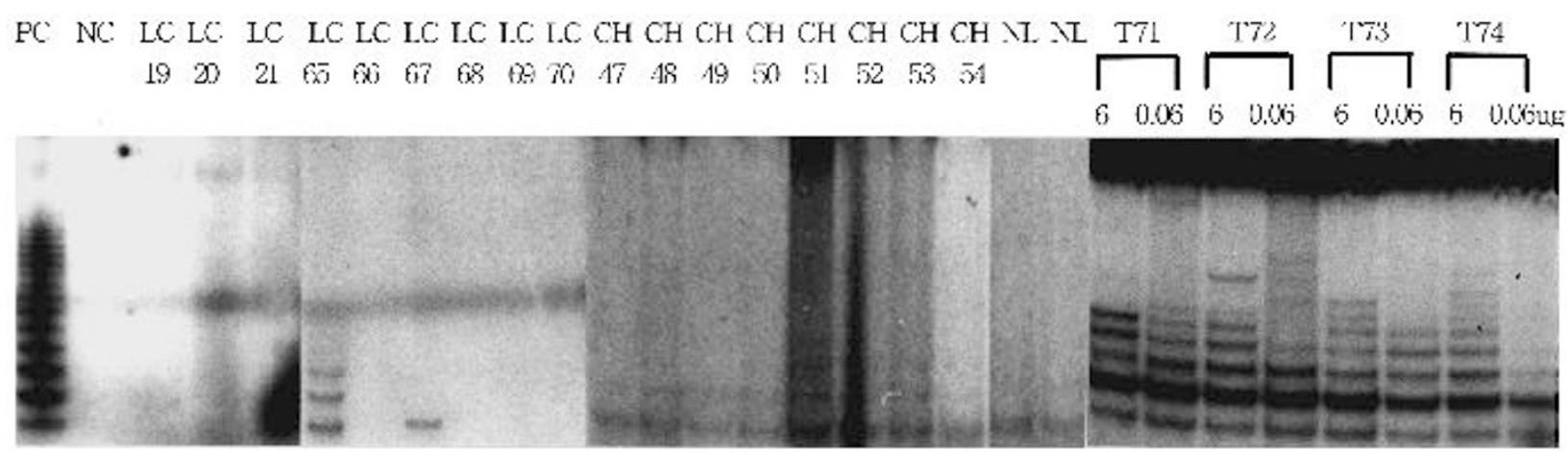
developed hepatocellular carcinoma, when evaluated at 2 years later after the detection of telomerase acitivity in the tissue specimens.

Among 16 patients with hepatocellular carcinoma, in whom a pair of both tumor and non-tumor were available, the enhancement of the telomerase activity in the surrounding non-tumor liver tissues was identified in 4 cases (25\%); 1 chronic hepatitis and 3 cirrhosis. (Table 2 )

There was no difference in the frequency of the telomerase activity in accordance with the differentiation grades of the hepatocellular carcinoma; well differentiated $(3 / 4)$, moderately differentiated (9/10), and poorly differentiated $(7 / 10)$. Also, no other natures in hepatocellular carcinoma were associated with the telomerase activity. (Table 3)

\section{Discussion}

In most immortalized cells, telomeres are stabilized at a length that depends on a balance between the loss of telomeric repeats at each cycle of DNA replication and the telomeric elongation by the enhancement of the telomerase activity. It has been suggested that telomerase is repressed in somatic tissues to reduce the probability of cancer in long-lived organism like human (Allsopp et al., 1992; Vaziri et al., 1993). A recently developed method to measure the telomerase activity, so-called TRAP, is highly sensitive and reproducible as a PCR-based assay, so that it has been possible to examine this hypothesis
Table 3. Correlation between the enhancement of telomerase activity and clinicopathologic features of hepatocellular carcinoma.

Increased telomerase activity No. of cases Number \%

\begin{tabular}{|c|c|c|c|c|}
\hline \multicolumn{5}{|l|}{ Significance } \\
\hline TNM stage & & & & No \\
\hline$|-| \mid$ & 4 & 3 & $75 \%$ & \\
\hline III & 3 & 3 & $100 \%$ & \\
\hline IV & 17 & 13 & $76 \%$ & \\
\hline Size (long diameter) & & & & No \\
\hline smaller than $5 \mathrm{~cm}$ & 5 & 3 & $75 \%$ & \\
\hline between $5 \mathrm{~cm}$ and $10 \mathrm{~cm}$ & 6 & 6 & $100 \%$ & \\
\hline larger than $10 \mathrm{~cm}$ & 13 & 10 & $77 \%$ & \\
\hline Multiplicity & & & & No \\
\hline single & 7 & 4 & $57 \%$ & \\
\hline multiple & 17 & 15 & $88 \%$ & \\
\hline Differentiation grade & & & & No \\
\hline well & 4 & 3 & $75 \%$ & \\
\hline moderately & 10 & 9 & $90 \%$ & \\
\hline poorly & 10 & 7 & $70 \%$ & \\
\hline Alpha-fetoprotein in serum & & & & No \\
\hline lower than $500 \mathrm{ng} / \mathrm{ml}$ & 9 & 8 & $89 \%$ & \\
\hline higher than $500 \mathrm{ng} / \mathrm{ml}$ & 15 & 11 & $73 \%$ & \\
\hline Viral markers & & & & No \\
\hline HBs-Ag-positive & 18 & 14 & $78 \%$ & \\
\hline Anti-HCV-positive & 2 & 2 & $100 \%$ & \\
\hline
\end{tabular}

Table 2. Telomerase activity and tumor nature of patients with hepatocellular carcinoma who were available for both tumor ( $\mathrm{T}$ ) and non-tumor (NT) liver tissues (N=16). HBV, Hepatitis $B$ virus; HCV, Hepatitis C virus; CAH, Chronic active hepatitis; TNM: Cancer staging system recommended by the American Joint Committee (Carr et al, 1983).

\begin{tabular}{|c|c|c|c|c|c|c|c|c|c|c|c|}
\hline Case No. & Age/Sex & $\begin{array}{l}\text { Hepatitis } \\
\text { virus }\end{array}$ & $\begin{array}{l}\text { Non-tumor } \\
\text { liver }\end{array}$ & $\begin{array}{l}\text { TNM } \\
\text { stage }\end{array}$ & $\begin{array}{l}\text { Diferentiation } \\
\text { Grade }\end{array}$ & $\begin{array}{l}\text { Tumor } \\
\text { number }\end{array}$ & $\begin{array}{l}\text { Growth } \\
\text { pattern }\end{array}$ & $\begin{array}{l}\text { AFP } \\
(\mathrm{ng} / \mathrm{ml})\end{array}$ & $\begin{array}{c}\text { Telomerase } \\
\mathrm{T}\end{array}$ & $\begin{array}{l}\text { activity } \\
\text { NT }\end{array}$ & $\begin{array}{l}\text { Survival } \\
\text { (months) }\end{array}$ \\
\hline 71 & $35 / M$ & HBV & Cirrhosis & IVa & well & multiple & nodular & 1536 & +++ & - & 3 \\
\hline 72 & $40 / \mathrm{M}$ & $\mathrm{HCV}$ & Cirrhosis & III & moderate & single & nodular & 526 & +++ & - & - \\
\hline 73 & $32 / \mathrm{M}$ & HBV & Cirrhosis & IVa & moderate & multiple & nodular & 8 & +++ & - & 18 (alive) \\
\hline 74 & $67 / M$ & $\mathrm{HCV}$ & Cirrhosis & III & well & single & nodular & 868 & +++ & \pm & 10 (alive) \\
\hline 75 & $52 / M$ & HBV & Cirrhosis & IVa & moderate & single & infiltrative & 1539 & - & - & 10 (alive) \\
\hline 76 & $45 / M$ & HBV & Cirrhosis & III & well & single & nodular & 1161 & +++ & - & 8 (alive) \\
\hline 77 & $60 / F$ & $\mathrm{HCV}$ & Cirrhosis & III & poor & single & nodular & 1507 & +++ & \pm & 3 \\
\hline 78 & $64 / F$ & HBV & Cirrhosis & IVa & poor & multiple & nodular & 53.7 & +++ & - & - \\
\hline 79 & $44 / \mathrm{M}$ & HBV & Cirrhosis & IVa & moderate & multiple & nodular & 1453 & +++ & - & - \\
\hline 80 & $50 / M$ & HBV & Cirrhosis & IVa & poor & multiple & nodular & 4.2 & +++ & - & 4 \\
\hline 81 & $51 / M$ & HBV & Cirrhosis & III & moderate & multiple & nodular & 94 & +++ & - & 5 \\
\hline 82 & $40 / \mathrm{M}$ & HBV & Cirrhosis & IVa & poor & single & nodular & 660 & - & - & 10 \\
\hline 83 & $52 / \mathrm{M}$ & HBV & Cirrhosis & IVa & poor & single & infiltrative & 5 & - & - & 6 \\
\hline 84 & $54 / \mathrm{M}$ & $\mathrm{HCV}$ & $\mathrm{CAH}$ & IVa & moderate & multiple & nodular & 1279 & +++ & + & 6 \\
\hline 85 & $42 / \mathrm{M}$ & HBV & Cirrhosis & IVa & well & multiple & infiltrative & 1057 & +++ & \pm & 8 \\
\hline 86 & $66 / M$ & HBV & Cirrhosis & IVa & moderate & multiple & infiltrative & 1150 & +++ & - & 9 \\
\hline
\end{tabular}


by measuring the telomerase activity in various cells and tissues in vitro and in vivo (Kim et al., 1994).

It is a current opinion that the telomerase is specifically activated in malignant tumors and germ cells and hematopoietic stem cells (Counter et al., 1995). By a series of data reported by Hiyama et al., the telomerase activity was detected by $94 \%$ of neuroblastomas (1995), $80 \%$ of lung cancers (1995), 85\% of gastric cancers (1995), 93\% of breast cancers (1996), and $95 \%$ of pancreatic cancers (1997). And most colorectal cancers (93\%) also showed telomerase activation (Chadeneau et al., 1995).

In the present study, telomerase was strongly activated in $79 \%$ of the hepatocellular carcinomas, which were similar to the results reported by other groups; $84.8 \%$ (Tahara et al., 1995), 80\% (Nouso et al., 1996) and 85\% (Kojima et al., 1997), respectively. On the contrary, the telomerase activity in non-tumorous liver tissues was detectable weakly only by $16.9 \%$. Other groups also reported that some non-tumorous liver tissues without hepatocellular carcinoma might have a weak activation of telomerase; 17\% (Nouso et al., 1996) and 9\% (Kojima et al., 1997). These support strongly that the high enhancement of telomerase expression is an essential part for malignant transformation during hepatocarcinogenesis like other malignant cancers and for the immortality of the transformed cells.

Among our non-cancer patients, telomerase was expressed more frequently in cirrhosis $(24 \%)$ than in chronic hepatitis (4\%), but such observation was not coincidental by other groups (Tahara et al., 1995; Nouso et al., 1996). Furthermore, hepatocellular carcinoma has not developed among non-cancerous patients with the weak telomerase activity by TRAP for at least 2 years follow-up. Therefore, further studies will be needed to clarify the significance of telomerase expression in such a group of patients with chronic hepatitis or cirrhosis.

It has been suggested by Nouso et al. (1996) and Kojima et al . (1997) that there is a correlation between differentiation grades in malignant phenotype and telomerase activity. However, in the present study, we could not see such relationship in hepatocellular carcinoma pathology. In addition, we could not find out any tumor natures and laboratory variables correlated with strong telomerase activation in hepatocellular carcinomas.

Some hepatocellular carcinomas had no telomerase expression, which was suggested as a reason by Hiyama et al. (1995) that certain tissue factor might inhibit Taq DNA polymerase in such group of the patients. So, the telomerase activity was measured in serially diluted samples as described by other groups (Tahara et al., 1995; Yashima et al., 1997), but we could not observe such paradoxical phenomena. Additionally, we could see 'all-or-none' phenomenon, "strongly positive or negative", in the results. These indicate that certain other factor(s), not identified as of yet, may influence negatively the TRAP method or telomerase activity. Another possibility might be the inactivation of telomerase during freezing and preparing tissues.

In summary, the present study support that hepatocellular carcinomas usually have strong enhancement in the telomerase activity, whatever the cancer nature is (stage, tumor size, number of tumor nodules, growth patterns, cellular types, vascular involvement, and differentiation grade). These charateristics may be helpful for the differential diagnosis between benign and malignant nodules and also for the development of specific treatment of hepatocellular carcinoma.

\section{Acknowlegement}

This study was supported by Grants-in-Aids for Catholic Medical Science Research Foundation from The Catholic University of Korea.

\section{References}

Allsopp, R. C., Vaziri, H., Petterson, C., Goldstein, S., Younglas, E. V., Fute, A. B., Greider, C. W. and Harley, C. B. (1992) Telomere length predicts replicative capacity of human fibroblasts. Proc. Natl. Acad. Sci. U.S.A. 89: 10114-10117

Blackburn, E. H. (1991) Structure and function of telomeres. Nature 350: 569-573

Blackburn, E. H. and Gall, J. G. (1978) A tandemly repeated sequence at the termini of the extrachromosomal RNA genes in Tetrahymena. J. Mol. Biol. 120: 33-53

Carr, D.T. (1983) Is staging of cancer of value? Cancer 51: 2503-2505

Chadeneau, C., Hay, K., Hirte, H. W., Gallinger, S. and Bacchetti, S. (1995) Telomerase activity associated with acquisition of malignancy in human colorectal cancer. Cancer Res. 55: 253-2536

Counter, C. M. (1992) Telomeric shortening associated with chromosome instability is arrested in immortal cells which express telomeric activity. EMBO J. 11: 1921-1929

Counter, C. M., Botelho, F. M., Wang, P., Harley, C. B. and Bacchetti, S. (1994) Telomerase activity in human ovarian carcinoma. Proc. Natl. Acad. Sci. U.S.A. 91: 2900-2904

Counter, C. M., Gupta, J., Harley, C.B., Lever, B. and Bacchetti, S. (1995) Telomerase activity in normal leukocytes and in hematologic malignancies. Blood 85: 2315-2320

Counter, C. M., Hirt, H. W., Bacchetti, S. and Harley, C. B. (1994) Stabili-zation of short telomeres and telomerase activity accompany immortali-zation of Epstein-Barr virus transformed human B lymphocytes. J. Virol. 68: 3410-3414

Edmondson, H. A. and Steiner, P.E. (1954) Primary carcinoma of the liver: a study of 100 cases among 48,900 necropsies. Cancer 7: 462-503

Greider, C. W. and Blackburn, E. H. (1985) Identification of a specific telomere terminal transferase activity in Tetrahymena extracts. Cell 43: 404-413

Harley, C. B., Futcher, A. B. and Greider, C. W. (1990) Telomeres shorten during aging human fiboblasts. Nature 345 : $458-460$

Hiyama, K., Hiyama, E., Ishioka, S., Yamakido, M., Inai, K., Gazdar, A. F., Piatyszek, M. A. and Shay, J. W. (1995) Telomerase activity in small-cell and non-small-cell lung cancers. J. Natl. Cancer Inst. 87: 895-902

Hiyama, E., Gollahan, L., Kataoka, T., Kuroi, K., Yokoyama, T., Gazdar, A. F., Hiyama, K., Piatyszek, M. A. and Shay, J. W. (1996) Telomerase activity in human breast tumors. J. Natl. Cancer Inst. 88: 116-122

Hiyama, E., Hiyama, K., Yokoyama, T., Matsuura, Y., Piatyszek, M. A. and Shay, J. W. 
(1995) Correlating telomerase activity levels with human neuroblastoma outcomes. Nat. Med. 1: 249-255

Hiyama, E., Takashi, K., Shinbara, K., Iwao, T., Itoh, M., Hiyama, K., Shay, J. W., Matsuura, Y. and Yokoyama, T. (1997) Telomerase activity is detected in pancreatic cancer but not in benign tumors. Cancer Res. 57: 326-331

Hiyama, E., Yokoyama, T., Tatsumoto, N., Hiyama, K., Imamura, Y., Murakami, Y., Kodama, T., Piatyszek, M. A,, Shay, J. W. and Mastuura, Y. (1995) Telomerase activity in gastric cancer. Cancer Res. 55: 2358-3262

Kim, N. W., Piatyszek, M. A., Prowse, K. R., Harley, C. B., West, M. D., Ho, P. C., Coveiello, G. M., Wright, W. E., Weinrich, S. L. and Shay, J. W. (1994) Specific association of human telomerase activity with immortal cells and cancer. Science 66 : 2011-2015

Kitada, T., Seki, S., Kawakita, N., Kuroki, T. and Monna, T. (1995) Telomere shortening in chronic liver diseases. Biochem. Biophys. Res. Commun. 211: 33-39

Kojima, H., Yokosuka, O., Imazeki, F., Saisho, H. and Omata, M. (1997) Telomerase activity and telomere length in hepatocellular carcinoma and chronic liver disease. Gastroenterology 112: 493-500

Lindsey, J., McGill, N. I., Lindsey, L. A., Green, D. K. and Kooke, H. J. (1991) In vivo of telomeric repeates with age in humans. Mutat. Res. 256: 45-48

Moyzis, R. K., Buckingham, J. M., Cram, L. S., Dani, M., Deaven, L. L. and Jones, M. D. (1988) A highly conserved repetitive DNA sequence, (TTAGGG)n, present at the telomeres of human chromosomes. Proc. Natl. Acad. Sci. U.S.A. 85: 6622-6626

Nouso, K., Urabe, Y., Hagashi, T., Hino, N., Ashisa, K., Kinugasa, N., Yoshisa, K., Uematsu, S. and Tsuji, T. (1996) Telomerase as a tool for the differential diagnosis of human hepatocellular carcinoma. Cancer 78: 232-236

Ohashi, K., Tsutsumi, M., Nakajima, Y., Kobitsu, K., Nakano, H. and Konishi, Y. (1996) Telomere changes in human hepatocellular carcinomas and hepatitis virus infected noncancerous livers. Cancer 77: 1747-17551

Sharma, S.K., Babitch, J.A.(1980) Application of Bradford's protein assay to chick brain subcellular fractions. J Bioch Biophy Meth 2: 247-250.

Tahara, H., Nakanishi, T., Kitamoto, M., Nakashino, R., Shay, J. W., Tahara, E., Kajiyama, G. and Ide, T. (1995) Telomerase activity in human liver tissues: comparison between chronic liver disease and hepatocellular carcinomas. Cancer Res. 55: 27342376

Vaziri, H., Schachter, F., Uchisa, I., Wei, L., Zhu, X., Effros, R., Cohen, D. and Harley C. B. (1993) Loss of telomeric DNA during aging of normal and trisomy 21 human lymphocytes. Am. J. Hum. Genet. 52: 661-667

Yashima, K., Litzky, L. A., Kaiser, L., Rogers, T., Lam, S., Wistuba, I. I., Milchgrub, S., Srivastava, S., Piatyszek, M. A., Shay, J. W. and Gazdar, A. F. (1997) Telomerase expression in respiratory epithelium during the multistage pathogenesis of lung carcinomas. Cancer Res. 57: 2373-2377 